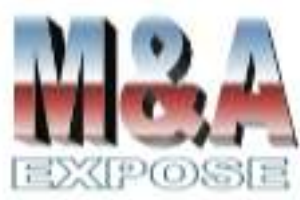

http://jurnal.usahid.ac.id/index .php/accounting
${ }^{1}$ Magister Manajemen Universitas Sahid Jakarta hkadarisman@yahoo.com ${ }^{2}$ Magister Manajemen Universitas Sahid Jakarta arienafiah@gmail.com

\section{Hubungan e-Word of Mouth dan Citra Merk dengan Minat Membeli pada Perbankan Syariah di Indonesia}

\author{
Haris Kadarisman ${ }^{1}$, Nafiah Ariyani ${ }^{2}$
}

\section{Abstrak}

Era digital menawarkan banyak peluang sekaligus ancaman, oleh karenanya setiap organisasi harus menganalisanya dengan cermat untuk meningkatkan kinerja perusahaan. Penelitian ini bertujuan untuk mengetahui hubungan e-word of mouth dan citra merek terhadap minat membeli pada industri perbankan syariah di Indonesia, yang belum banyak mengadopsi kemajuan teknologi digital dalam operasinya. Populasi pada penelitian ini adalah pemilik rekening bank konvensional. Metode sampling yang digunakan adalah non probabilistik dengan teknik convenience. Teknik pengambilan data dilakukan dengan penyebaran kuesioner langsung dan melalui email dengan jawaban menggunakan Skala Likert. Metode analisis data menggunakan SEM (Structural Equation Modelling). Hasil penelitian menunjukan bahwa variabel e-word of mouth berpengaruh terhadap citra merek dan minat membeli, demikian pula citra merek berpengaruh terhadap minat membeli. E-word of mouth berpengaruh paling besar terhadap minat membeli daripada citra merek.

Kata kunci: citra merek, e-word of mouth, perbankan syariah, minat membeli.

\section{Abstract}

The digital era offers many opportunities as well as threats, so every organization must analyze it carefully to improve the company's performance. This study aims to find out the relationship of e-word of mouth and brand image to buying interest in the sharia banking industry in Indonesia, which has not adopted many advances in digital technology in its operation. The population in this study is the owner of a conventional bank account. The sampling method used is non probabilistic with convenience technique. The data retrieval technique was done by distributing the questionnaire directly and by email with the answer using Likert Scale. Method of data analysis using SEM (Structural Equation Modeling). The findings showed that e-word of mouth variables affect the brand image and buying interest, as well as brand image affect the buying interest. E-word of mouth has the greatest influence on buying interest rather than brand image.

Keywords : brand image; e-word of mouth; syariah banking; purchase intention. 


\section{PENDAHULUAN}

Pertumbuhan dan perkembangan dunia digital di Indonesia berkembang amat pesat, hal ini dapat terlihat dari jumlah pengguna Internet di Indonesia tahun 2016 yang mencapai $51,5 \%$ dari total jumlah penduduk Indonesia. Bedasarkan latar belakang demografi pengguna internet di Indonesia, mayoritas berusia 35-44 tahun dengan jumlah sebesar 38,7 juta pengguna atau $29,2 \%$, selanjutnya, di peringkat kedua dan ketiga adalah pengguna internet berusia 25-34 tahun dan 10-24 tahun. Hal ini mengindikasikan bahwa para pengguna internet di Indonesia mayoritas berada dalam usia produktif (Assosiasi Penyelenggara Jasa Internet Indonesia/APJII, 2016).

Dalam konteks global tahun 2017, Indonesia menduduki peringkat kelima setelah Cina, India, Amerika Serikat, dan Brazil, sebagai negara dengan pengguna internet terbanyak di dunia. Hasil tersebut mengacu pada data dari lembaga riset pasar dunia, yakni Internet World Stat.com (2017).

Tabel 1. Negara Pengakses Internet Terbesar Tahun 2017 (dalam Juta)

\begin{tabular}{ccc}
\hline No. & Negara & Jumlah \\
\hline 1 & Cina & 738,5 \\
2 & India & 462,1 \\
3 & Amerika & 286,9 \\
4 & Brazil & 139,1 \\
5 & Indonesia & 132,7 \\
\hline
\end{tabular}

Sumber : www.internetworld.stats.com/top.20.

Data jumlah pengguna internet pada Tabel 1 berbanding lurus dengan tumbuhnya jumlah pengguna media sosial di Indonesia, dimana saat ini penggunaan media sosial di Indonesia didominasi oleh media social Facebook (71,6 juta), Instagram (19,9 juta), Youtube (14,5 jt), Google+ (7,9 juta) dan Twitter (7,2 juta).

Asosiasi E-commerce seluruh Indonesia mengungkapkan bahwa penduduk Indonesia menghabiskan tidak kurang dari 55\% waktunya untuk mengakses internet atau online, secara rinci Idea menjelaskan bahwa masyarakat Indonesia selama 106 menit dalam sehari menggunakan mobile phone, 80 menit menonton TV, 59 menit online di depan laptop, dan sisanya masing-masing 28 menit dan 24 menit dihabiskan untuk mendengarkan radio dan membaca majalah atau koran.

Tabel 2. Perilaku Pengguna Internet di Indonesia Tahun 2016

\begin{tabular}{llrr}
\hline \multirow{2}{*}{ No } & \multirow{2}{*}{ Jenis Perangkat } & \multicolumn{2}{c}{ Jumlah Pengguna Internet } \\
\cline { 3 - 4 } & & Dalam Juta & Persentase \\
\hline 1 & Mobile Phone & 63,1 & 47,6 \\
2 & MobilePhone\& Komputer & 67,2 & 50,7 \\
3 & Komputer & 2,2 & 1,7 \\
\multicolumn{2}{l}{ Total } & 132,6 & 100 \\
\hline \multicolumn{2}{l}{ Sumber : APJII, (2016). }
\end{tabular}


Tabel 2 merangkum jenis perangkat yang sering dipakai oleh masyarakat Indonesia untuk mengakses internet. Penggunaan komputer desktop saat ini sudah hampir jarang dilakukan oleh banyak orang mengingat kemampuan mobilephone yang ada saat ini sudah bisa digunakan seperti komputer, data APJII tahun 2016 menunjukan bahwa pengguna internet menggunakan handphone sudah melebihi penggunaan internet dari komputer.

Data pada Tabel 1 dan Tabel 2 menggambarkan potensi yang sangat besar bagi bisnis di Indonesia, tak terkecuali bagi bisnis perbankan. Secara umum perbankan di Indonesia saat ini sedang menuju kepada era digital yang menjanjikan peningkatan pada customer experience nasabah. Digital banking tidak lagi berupa bisnis yang melibatkan 'uang' melainkan bisnis yang menghargai 'nilai'. Nilai ini tidak hanya memberikan manfaat fungsional tetapi juga pengalaman secara holistik kepada nasabah.

Adopsi digital banking pada perbankan konvensional di Indonesia lebih maju dibandingkan dengan bank syariah. Hal ini berdampak terhadap nasabah. Perkembangan jumlah nasabah bank konvensional di Indonesia lebih baik jika dibandingkan dengan perkembangan jumlah nasabah bank syariah. Kondisi ini terkait dengan masih banyak masyarakat yang beranggapan bahwa bank syariah belum selengkap, semodern, dan sebagus bank konvensional.

Selain itu, perkembangan industri perbankan syariah masih lambat meskipun potensinya sangat besar, terkait dengansekitar 85 persen penduduk Indonesia mayoritas muslim. Meskipun telah banyak analisa menyatakan bahwa perbankan syariah tidak hanya diadopsi oleh orang Muslim. Ironisnya, penguasaan pasar bank syariah di industri perbankan nasional masih kalah jauh dengan bank konvensional. Salah satu penyebabnya karena produk perbankan syariah dinilai masih kalah kompetitif dibandingkan produk bank konvensional.

Berkembangnya era digital harus dapat dimanfaatkan oleh perbankan syariah. Hal ini didukung oleh banyaknya nasabah bank konvensional yang menuangkan pendapat positifnya di internet mengenai bank syariah. Informasi tersebut merupakan promosi gratis dan powerfull bagi mereka yang akan mengambil keputusan untuk menjadi nasabah bank syariah, sehingga perbankan harus lebih proaktif.Pemanfaatan ulasan positif dapat memperkuat atau melemahkan brand image sebelum calon nasabah memutuskan untuk memilih dari sekian banyak pilihan perbankan yang ada. Penggunaan sarana media sosial untuk melakukan promosi adalah hal yang sangat baik mengingat didalam media sosial opini seseorang sangat berpengaruh terhadap keputusan pembelian. Sudah sangat umum saat ini apabila seseorang akan melakukan pembelian barang atau jasa akan melihat komentar di media sosial sebagai referensi.

Hal inilah yang akan menjadi focus penulis dalam penelitian ini. Secara khusus, penelitian ini akan menganalisis peran purchase intention dalam industri perbankan syariah sebagai dampak dari e-word of mouth dan brand image. Kemudian penelitian ini juga menganalisis pengaruh masing-masing e-word of mouth dan brand image terhadap purchase intention.

\section{TINJAUAN PUSTAKA}

Purwarna et. al., (2017) mengungkapkan bahwa teknologi digital telah mengubah cara manusia dalam berkomunikasi, bertindak, dan mengambil keputusan. Aktivitas pemasaran pun tidak lepas dari pengaruh teknologi digital. Istilah pemasaran berbasis digital 
(digital marketing) telah mengalami evolusi dari awalnya kegiatan pemasaran barang dan jasa yang menggunakan saluran digital hingga pengertian yang lebih luas yaitu proses memperoleh konsumen, membangun preferensi konsumen, mempromosikan merek, memelihara konsumen, dan meningkatkan penjualan.

Dominici (2009) dan Chen (2006) menyoroti pentingnya penyesuaian marketing mix di era digital. Kedua peneliti tersebut mengungkapkan bahwa bauran pemasaran konvensional yang terdiri dari product, price, promotion dan place tidak memadai lagi untuk memusakan pelanggan. Bauran pemasaran yang dinilai cocok dan relevan di era digital saat ini adalah precision, payment, personalization, push \& pull, product, price, place, promotion.

Kemunculan teknologi internet telah menciptakan sebuah paradigma baru dalam komunikasi word of mouth dan menjadi awal kemunculan dari istilah e-wordof mouth. Word of mouth pada awalnya disebut dengan ide orang-ke-orang dan percakapan antara konsumen tentang produk dan jasa yang menyebardi seluruh dunia (Chatterjee, 2001; Sen \& Lerman, 2007). Penyebaran yang dilakukan melalui internet disebut sebagai komunikasi e-word of mouth (Chatterjee, 2001; Godes and Mayzlin, 2004; Brown et al., 2007; Xia and Bechwati, 2008). Henning et al. (2004) menyatakan bahwa komunikasi e-word of mouth merupakan pernyataan positif atau negatif yang dibuat oleh konsumen mengenai produk atau jasa perusahaan dimana informasi ini tersedia bagi orang-orang melalui media internet. Melalui mobile internet yang semakin populer, pelanggan dapat membaca rekomendasi secara online untuk produk yang mereka minati, yang dapat memberikan dampak yang kuat pada keputusan pembelian mereka (Jalilvand and Samiei, 2012).

Salah satu dari bauran pemasaran yang utama pada era digital adalah adalah citra merek yang merupakan bagian dari bauran produk. Citra merek sangat mempengaruhi perilaku pembelian di era ini. Citra merek dapat didefinisikan sebagai pengaruh kekuatan nama, istilah, tanda, simbol, atau desain, atau kombinasi dari semuanya yang cenderung mengidentifikasi barang dan jasa dari satu penjual atau kelompok penjual dan untuk membedakannya dari produk pesaing (Kotler and Keller, 2014).

Studi perilaku konsumen sebagai disiplin ilmu pemasaran yang terpisah dimulai ketika para pemasar menyadari bahwa para konsumen tidak selalu bertindak atau memberikan reaksi seperti yang dikemukakakn oleh teori pemasaran. Walaupun pendekatan "saya juga" kadang-kadang merupakan mode, banyak konsumen menolak untuk memakai produk yang sama dengan yang dipakai oleh orang lainnya.

Purchase intention atau niat untuk melakukan pembelian adalah niat yang timbul dari proses pembelajaran dan penyelesaian masalah pada diri calon konsumen dalam menentukan keputusan untuk memilih atau menggunakan suatu merek atau produk. Hasil pembelajaran tersebut tidak terlepas dari peran para pelaku pemasaran yang secara agresif dan kreatif bersaing melakukan pendekatan-pendekatan pemasaran untuk menarik perhatian calon konsumen potensial yang pada umumnya hanya memiliki informasi terbatas mengenai merek-merek pada kategori produk tersebut (Wang\& Yang, 2010).

Lewis \& chambers (2000) dan Litvin et al. (2008) mengungkapkan bahwa membeli produk dan layanan yang tak berwujud membawa resiko lebih tinggi, sehingga pelanggan lebih bergantung pada hubungan interpersonal e-word of mouth. Terlepas dari dampak signifikan dari e-word of mouth pada segmen manufaktur, beberapa penelitian telah dilakukan untuk menganalisis e-word of mouth dalam bidang otomobil. Temuan penelitian terdahulu menunjukkan bahwa pesan e-word of mouth dapat menghubungkan citra merk dan niat pembelian. 


\section{METODE PENELITIAN}

Variabel penelitian ini terdiri dari tiga variabel berikut, yaitu

a. e-word of mouth, meliputi dimensi platform assistance, expressing positive emotions, economic incentives, helping the company, dan concern for other;

b. brand image, meliputi dimensi favorability of brand association, strenght of brand association, dan uniqueness of brand association;

c. purchase intention.

Populasi penelitian adalah nasabah bank konvensional terkait dengan variabel minat membeli. Sampel penelitian berjumlah 200 orang yang ditentukan dengan metode non probabilistic purposive sampling, dengan kriteria belum pernah menggunakan produk dari perbankan syariah, dan pernah membaca ulasan produk perbankan syariah melalui internet.

Teknik pengambilan data dilakukan dengan penyebaran kuesioner dengan skala Likert 1 (sangat tidak setuju) hingga 5 (sangat setuju). Kuesioner dibagikan langsung kepada responden yang telah dikumpulkan di suatu ruang dan melalui email bagi yang tidak dapat secara langsung memberikan pendapatnya. Metode analisis data yang digunakan adalah uji validitas dan reliabitas, uji statistik deskriptif yang dilihat dari nilai rata-rata dan uji inferensial untuk menguji hipotesis penelitian. Seluruh analisa data dilakukan menggunakan teknik Structural Equation Modelling dengan software SPSS dan LISREL.

Model penelitian yang digunakan adalah sebagai berikut :

Gambar 1. Model Penelitian

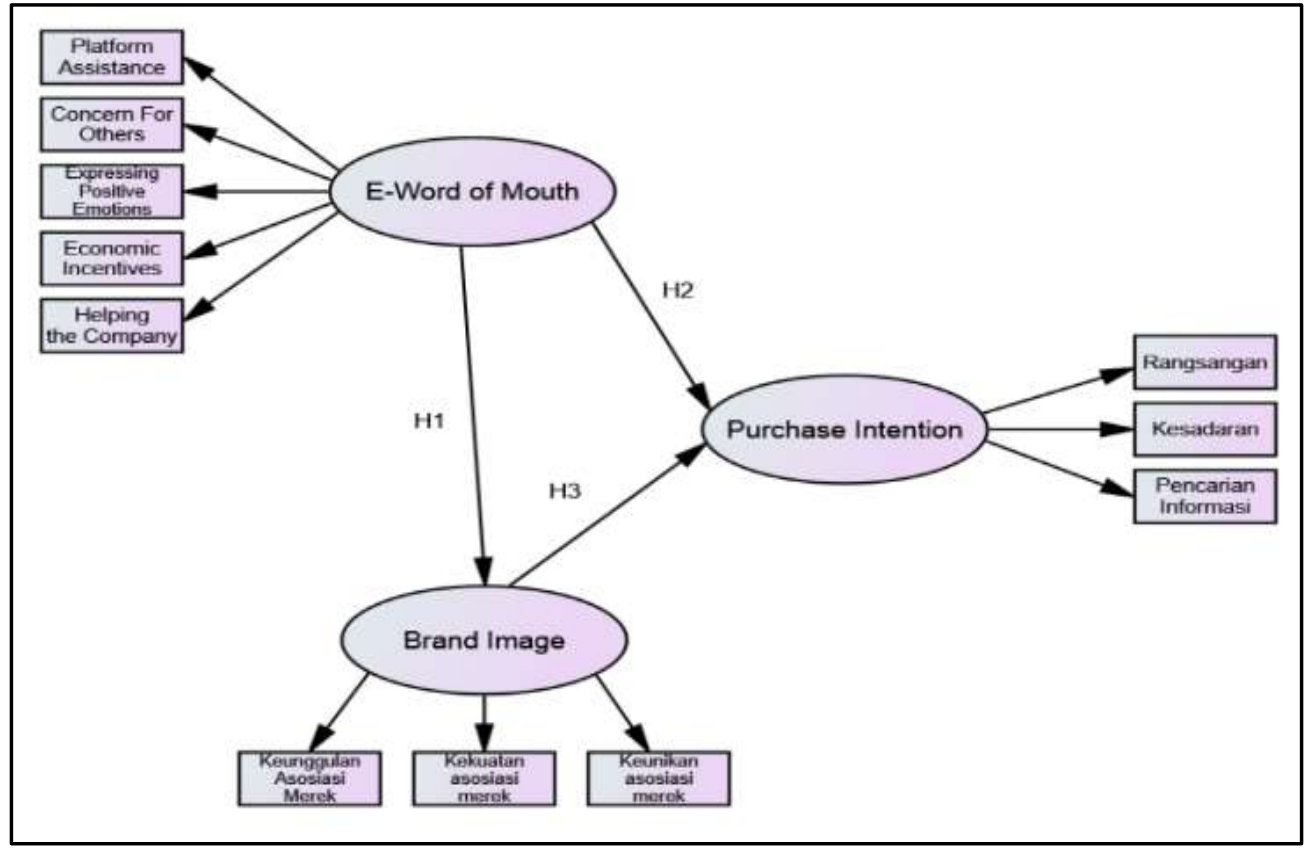

Adapun hipotesis yang diajukan pada penelitian ini adalah sebagai berikut :

$\mathrm{H}_{1}$ : Terdapat hubungan positif $e$-word-of-mouth terhadap brand image.

$\mathrm{H}_{2}$ : Terdapat hubungan positif e-word-of-mouth terhadap purchase intention.

$\mathrm{H}_{3}$ : Terdapat hubungan positif brand image terhadap purchase intention. 


\section{HASIL DAN PEMBAHASAN}

Seluruh item pada instrumen yang digunakan pada analisa telah lolos dari uji validitas dan reliabilitas. Hasil penyebaran kuesioner secara statistik memiliki response rate sebesar 100 persen, karena dari 200 kuesioner yang disebar seluruhnya kembali dan layak untuk diolah. Profil demografi responden disajikan pada Tabel 3.

Tabel 3. Profil Demografi Responden

\begin{tabular}{lcc}
\hline \multicolumn{1}{c}{ Demografi } & Responden & Responden \\
\hline Jenis Kelamin & $44,0 \%$ Pria & $56,0 \%$ Wanita \\
Memiliki Produk Perbankan Syariah & $100 \%$ Tidak & $0,00 \%$ Ya \\
Usia & $44,5 \%$ usia 26-35 tahun & $50,0 \%$ usia $36-50$ tahun \\
Pendidikan & $68,5 \%$ Sarjana (S1/D4) & $22,5 \%$ Magister (S2) \\
Pernah membaca ulasan Perbankan Syariah & $100 \%$ Pernah & $0,00 \%$ Tidak Pernah \\
Media online yang digunakan & $64,0 \%$ Facebook & $16,0 \%$ Instagram \\
Penghasilan & $48,5 \%$ (Rp 3-5 juta) & $46,0 \%$ (>Rp 5 juta) \\
Pekerjaan & $74,0 \%$ Karyawan & $22,0 \%$ Wiraswasta \\
\hline
\end{tabular}

Sumber : data primer diolah

Statistik Deskriptif. Analisa statistik deskriptif dilakukan untuk menjelaskan secara terperinci karakteristik data, yang dalam hal ini dilihat dari nilai mean.Berikut adalah analisis hasil uji statistik deskriptif yang menjelaskan nilai rata-rata dari tiap variabel dalam penelitian ini.

Tabel 4. Hasil Metode Statistik Deskriptif Penelitian

\begin{tabular}{lccc}
\hline \multicolumn{1}{c}{ Variabel } & Mean & Standart Deviation & Kategori \\
\hline E word of mouth & 4,91 & 0,87 & Tinggi \\
Brand Image & 4,90 & 0,91 & Tinggi \\
Purchase Intention & 4,93 & 0,93 & Tinggi \\
\hline
\end{tabular}

Sumber : Hasil olah data SPSS.

Berdasarkan Tabel 4 ketiga variabel yang diteliti memiliki nilai rata-rata tinggi di atas 4 (skala 1-5). Pada variabel e-word of mouth menggambarkan bahwa para responden merasakan kemudahan dalam memperoleh informasi mengenai produk perbankan syariah melalui media online dan mereka menilai media online merupakan sarana yang tepat untuk berbagi informasi produk perbankan syariah. Responden juga merasakan mendapatkan berbagai informasi produk perbankan syariah terkait dengan info promo, paket produk, kualitas produk, dan hal-hal tersebut diyakini memicu para responden untuk membantu mempublikasikan produk perbankan syariah tersebut.

Nilai rata-rata variabel brand image menunjukkan para responden menilai produk perbankan syariah dapat dipercaya, menarik, memiliki berbagai varian, dan berkualitas tinggi. Selain itu, hal ini juga menggambarkan bahwa produk perbankan syariah di mata responden memiliki benefit yang bersaing, dapat diandalkan, serta memiliki konsep yang unik dan ciri khas tersendiri atau berbeda dengan produk perbankan lainnya.

Variabel purchase intention dengan nilai rata-rata tertinggi, mengindikasikan bahwa para responden menilai bahwa dengan pelayanan yang diberikan ke konsumen lain, membuat mereka menjadi berminat untuk berkunjung ke bank syariah dan kualitas produk 
perbankan syariah yang diberikan kepada konsumen terdahulu, membuat para responden menjadi berminat untuk membeli produk tersebut, serta kegiatan promosi yang dilakukan produk perbankan syariah membuat mereka menjadi berminat untuk membeli produk perbankan syariah di masa yang akan datang.

Ujian Kesesuaian Model. Untuk mengetahui kesesuaian model yang dibangun dalam penelitian ini dilakukan uji kesesuaian model (goodness-of-fit model) berdasarkan beberapa kriteria pengukuran (Hair, dkk 2010). Hasil uji ditampilkan pada Tabel 5.

Tabel 5. Hasil Uji Goodness-of-Fit Index Full Structural Model

\begin{tabular}{cccc}
\hline Goodness of Fit Index & Cut-Off Value & Hasil Pengukuran & Keputusan \\
\hline Absolute Fit Measures & & & \\
Chi-square & Diharapkan Kecil & 440,78 & Fit \\
Probability & $\geq 0.05$ & 0.0032 & Marginal \\
RMSEA & $\leq 0.08$ & 0.030 & Fit \\
Incremental Fit Measures & & & \\
NFI & $\geq 0.90$ & 0,98 & Fit \\
GFI & $\geq 0.90$ & 0,87 & Marginal \\
AGFI & $\geq 0.90$ & 0,85 & Marginal \\
CFI & $\geq 0.90$ & 1,00 & Fit \\
Parsimonius Fit Measures & & & \\
PNFI & $\geq 0.50$ & 0,90 & Fit \\
\hline
\end{tabular}

Sumber : hasil olah data LISREL.

Hasil uji kesesuaian model menggunakan nilai NFI mempunyai nilai cut-off sebesar $\geq$ 0,90 sedangkan hasil yang dicapai adalah sebesar 0,98 , sehingga model fit. Dari nilai CFI dengan kriteria yang harus dicapai sebesar $\geq 0,90$, hasil pengujian menunjukkan angka 01,00 maka model dinyatakan fit. Berdasarkan kriteria GFI dengan nilai cut-off $\geq 0,90$, hasil pengolahan menunjukkan nilai sebesar 0,87 maka model mempunyai kategori marginal fit.

Uji Hipotesis. Secara structural, hasil uji t yang menguji hubungan antar variabel secara parsial disajikan pada Gambar 2.

Gambar 2. Hasil Uji t Value

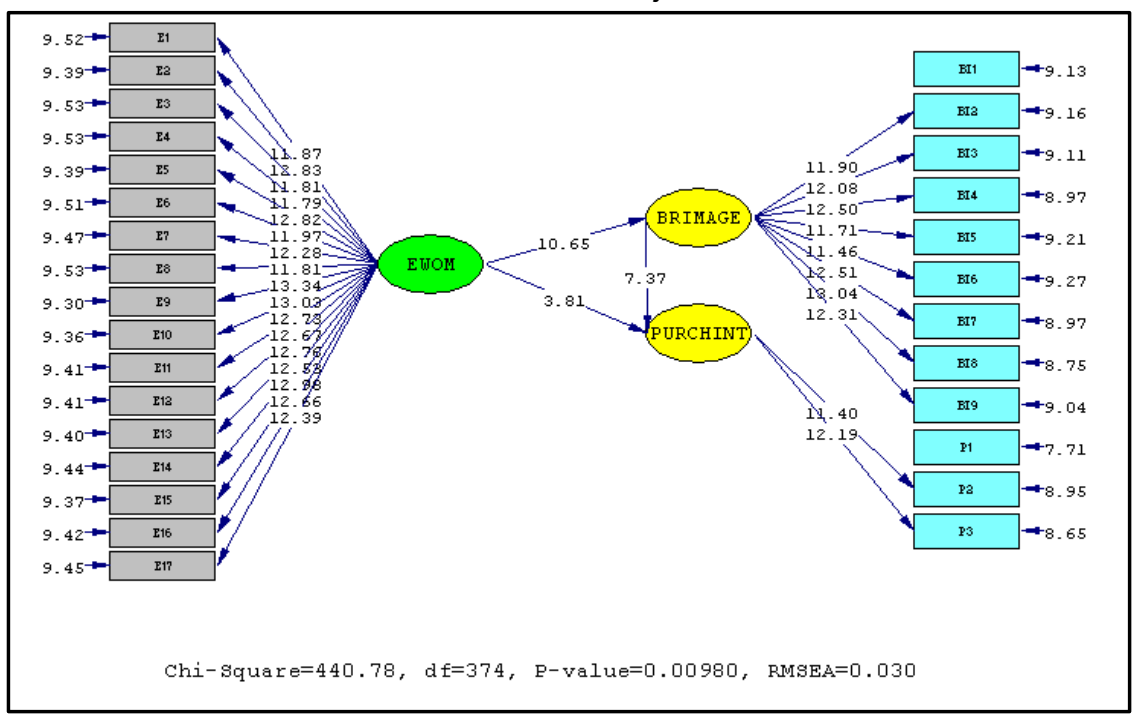

Sumber : Hasil olah LISREL. 
Hubungan $e$-Word of Mouth dan Citra Merk ...

Haris Kadarisman, Nafiah Ariyani

Uji hipotesis dilakukan menggunakan uji t dengan tingkat signifikasi $(\alpha)=0,05$, yang hasilnya disajikan pada Tabel 6 .

Tabel 6. Hasil Pengujian Hipotesis Penelitian

\begin{tabular}{cccc}
\hline & Hipotesis & t value & Correlation Weight \\
\hline H1 & E-word of mouth mempengaruhi brand image & 10.65 & 0.81 \\
H2 & E-word of mouth mempengaruhi purchase intention & 3.81 & 0.31 \\
H3 & Brand image mempengaruhi purchase intention & 7370.69 & \\
\hline
\end{tabular}

Sumber: hasil olah data LISREL

Dari hasil uji hipotesis dapat dinyatakan bahwa variabel e-word of mouth berpengaruh positif signifikan terhadap variabel brand image dengan bobot pengaruh sebesar 0,81 dan berpengaruh positif signifikan terhadap variabel purchase intention dengan bobot pengaruh sebesar 0,31 . Sedangkan variabel brand image berpengaruh positif signifikan terhadap purchase intention dengan bobot pengaruh sebesar 0,69.

Hasil uji hipotesis tersebut konsisten dengan penelitian Jalilvand \& Samiei (2012) yang menyatakan bahwa ada pengaruh positif signifikan variabel e-word of mouth terhadap brand image. Hasil ini juga mendukung temuan AC Nielsen (2007) yang mengungkapkan bahwa sebagian besar konsumen menganggap pendapat online dapat dipercaya seperti yang terdapat pada website suatu brand.

Hasil temuan ini juga sejalan dengan penelitian Chevalier \& Mayzlin (2006) yang menyatakan bahwa sebuah pesan komunikasi e-word of mouth memiliki arti penting bagi konsumen dalam mendapatkan informasi mengenai kualitas suatu produk atau jasa. Malilvand \& Samiei (2012) mengungkapkan bahwa word of mouth dan e-word of mouth yang positif memainkan peran penting dalam meningkatkan niat beli pelanggan, menciptakan brand \& corporate image yang menguntungkan dan dapat mengurangi pengeluaran promosi. Mereka juga menegaskan bahwa e-word of mouth merupakan salah satu faktor yang paling efektif dan signifikan dalam mempengaruhi brand image.

Hasil uji hipotesis kedua konsisten mendukung penelitian Zhang \& Tran (2009) dan Jalilvand \& Samiei (2012). Para konsumen semakin sering mencari ulasan produk secara online untuk mengumpulkan informasi produk sebelum melakukan pembelian (Adjei dkk 2009; Zhu \& Zhang, 2010) dan membentuk niat pembelian (Zhang dkk, 2009).

Hasil penelitian ini juga mendukung pernyataan Jalilvand \& Samiei (2012) di mana eword of mouth sebagai alat pemasaran yang kuat pada lingkungan internet. Pemasar dapat memanipulasi komunikasi e-word of mouth untuk menghubungkan perilaku pembelian pelanggan dan attitude. Word of mouth dan e-word of mouth yang positif memainkan peran penting dalam meningkatkan niat beli pelanggan, menciptakan citra perusahaan dan merek yang menguntungkan, dan mengurangi pengeluaran promosi.

Rowley (2001) menyarankan agar perusahaan komersial mencoba mengorganisir komunitas online daripada sekadar beriklan di internet. Studi tersebut menunjukkan betapa besar dampak potensial yang dapat dimiliki e-word of mouth terhadap proses pengambilan keputusan konsumen.

Hasil hipotesis kedua ini juga sejalan dengan penelitian Senecal \& Nantel (2004) yang meneliti pengaruh e-word of mouth terhadap pilihan produk dengan menggunakan studi eksperimental mengenai penggunaan sumber rekomendasi online oleh konsumen. Berbagai platform memfasilitasi e-word of mouth, seperti discussion boards dan alat 
komunikasi online lainnya, juga semakin dikenal karena bagaimana hal tersebut dapat mempengaruhi adopsi dan penggunaan produk dan layanan (Subramani \& Rajagopalan, 2003).

Hasil hipotesa ketiga mendukung penelitian Jalilvand \& Samiei (2012) yang membuktikan bahwa niat beli dapat dihubungkan dengan brand image. Brand image yang kuat, menguntungkan, dan unik berpengaruh positif dengan kerelaan untuk membayar harga premium dan brand equity yang lebih tinggi. Brand image yang dikomunikasikan dengan baik dapat membantu membangun brand's position, melindungi merek dari persaingan, meningkatkan kinerja merek di dalam pasar, dan berperan integral dalam membangun ekuitas merek jangka panjang (Aaker,1991; Keller, 1993; Park, 2008). Brand awareness yang tinggi dan brand image yang positif juga dapat meningkatkan efektivitas komunikasi pemasaran (Keller, 1993).

Hasil penelitian ini sejalan dengan temuan Wang \& Yang (2010) yang mengungkapkan bahwa brand awareness dan brand image merupakan sinyal penting yang terkait dengan bagaimana konsumen memandang merek dan membantu memprediksi perilaku pembelian mereka. Keller (1993) mengungkapkan bahwa perilaku pelanggan berkaitan dengan brand equity, yang terdiri dari dimensi brand awereness dan brand image, yang menjelaskan efek dari diferensiasi pengetahun merek terhadap respon pelanggan dan pemasaran suatu merek. Bukti empiris mengindikasikan bahwa brand equity mempengaruhi niat beli konsumen dalam beragam konteks (Ashill \& Sinha, 2004; Chang \& Liu, 2009). Berdasarkan penelitian yang dilakukan oleh Jalilvand \& Samiei (2012) ditemukan pengaruh positif brand image terhadap purchase intention.

Hasil penelitian secara keseluruhan menunjukkan bahwa melalui e-word of mouth produk perbankan syariah dapat dipercaya, menarik, memiliki berbagai varian, dan berkualitas tinggi. Selain itu, juga menggambarkan bahwa produk perbankan syariah memiliki benefit yang bersaing, dapat diandalkan, serta memiliki konsep yang unik dan ciri khas tersendiri atau berbeda dengan produk perbankan lainnya. Beragam hal tersebut terbukti memberikan dampak yang positif dan signifikan, yang mempengaruhi minat untuk berkunjung ke bank syariah. Kualitas produk perbankan syariah yang dipersepsikan oleh konsumen terdahulu meningkatkan minat untuk membeli produk tersebut. Selain itu, kegiatan promosi yang dilakukan perbankan syariah meningkatkan minat konsumen untuk membeli produk perbankan syariah di masa depan.

\section{KESIMPULAN}

Berdasarkan analisis data, dapat disimpulkan bahwa e-word of mouth berpengaruh positif signifikan terhadap brand image. Variabel e-word of mouth juga berpengaruh positif signifikan terhadap purchase intention. Media online merupakan sarana yang tepat untuk berbagi informasi produk perbankan syariah terkait dengan info promo, paket produk, kualitas produk. Hal-hal tersebut diyakini memicu mempublikasikan produk perbankan syariah. Beberapa faktor tersebut berdampak pada meningkatnya minat mereka untuk berkunjung ke bank syariah dan berminat memanfaatkan produk perbankan syariah di masa yang akan datang.

Selain itu, disimpulkan bahwa brand image berpengaruh positif signifikan terhadap purchase intention. Media sosial dimanfaatkan bukan hanya menjadi media penyebaran informasi produk perbankan syariah, melainkan juga dapat dimanfaatkan sebagai additional 
channel dari call center, sehingga operator/admin yang memegang kendali pada seluruh media sosial dapat memberikan feedback secara real-time untuk menjawab berbagai pertanyaan terkait dengan produk, layanan, promo, keluhan, saran, dan lain sebagainya.

Guna meningkatkan dan mengembangkan komunitas syariah dalam dunia maya, maka perbankan syariah hendaknya memanfaatkan berbagai news website maupun online media lainnya untuk dapat berinteraksi dengan membentuk suatu forum diskusi online yang difasilitasi perusahaan. Hal ini dapat menjadi media perbankan syariah di Indonesia untuk bertukar informasi produk secara dua arah, serta beragam layanan kepada para potential consumers. Peningkatan kualitas konten maupun artikel perlu dilakukan agar setiap konten yang didistribusikan melalui media sosial, official website, dan berbagai media online lainnya dapat memberikan efek viral dan terjadi interaksi positif terkait konten tersebut.

\section{DAFTAR PUSTAKA}

Aaker, D.A. 1991. Managing Brand Equity : Capitalizing on the Value of a Brand Name. The Free Press, New York, NY.

AC Nielsen. 2007. Trust in Advertising : A Global Nielsen Consumer Report. AC Nielsen, New York.

Adjei, M.T., Noble, S.M. \& Noble, C.H. 2009. The Influence of C2C Communications in Online Brand Communities on Customer Purchase Behavior. Journal of the Academy of Marketing Science. Vol. 38 No. 5, pp. 634-53.

Ashill, N.J. \& Sinha, A. 2004. An Exploratory Study Into The Impact of Components of Brand Equity and Country of Origin Effects on Purchase Intention. Journal of Asia-Pacific Business. Vol. 5 No. 3, pp. 27.

Asosiasi Penyelenggara Jasa Internet Indonesia (APJII). 2016. Infografis Penetrasi Pengguna Internet Indonesia. Buletin Assosiasi Penyelenggara Jasa Internet Indonesia.

Brown, J., Broderick, A.J. \& Lee, N. 2007. Word of Mouth CommunicationWithin Online Communities: Conceptualizing The Online Social Network. Journal of Interactive Marketing. Vol. 21 No. 3, pp. 2-20.

Chang, H.H. and Liu, Y.M. 2009. The Impact of Brand Equity on Brand Preference and Purchase Intentions in The Service Industries. The Service Industries Journal. Vol. 29 No. 12 , p. 1687.

Chatterjee, P. 2001. Online Reviews : Do Consumers Use Them?. Advances in Consumer Research. Vol. 28 No. 1, pp. 129-33.

Chen, C.Y., 2006. The Comparation of Structure Differences between Internet Marketing and Tradisional Marketing. pp. 397-417. Diakses dari https://www.coursehero.com.

Chevalier, J.A. and Mayzlin, D. 2006. The Effect of Word of Mouth on Sales : Online Book Reviews. Journal of Marketing Research. Vol. 43 No. 3, pp. 345-54.

Dominici, G.2008. Holonic Production System to Obtain Flexibility for Customer Satisfaction. pp. 251-254. Diakses dari www.scirp.org/Journal/Paperlnformation.aspx?paperlD $=161$.

Fitria, E.S and Dwijananda, I.M. 2016. Analisis Pengaruh Electronic Word of Mouth terhadap Proses Keputusan Pembelian (Studi pada GOJEK). E-Proceeding of Management. Vol. 3 No. 1, pp. 01-19.

Godes, D. and Mayzlin, D. 2004. Using Online Conversations to Study Word-of-Mouth Communication. Marketing Science. Vol. 23 No. 4, pp. 545-60.

Hair, J.F., et al. 2010. Multivariate Data Analysis. $7^{\text {th }}$ Edition. Prentice-Hall International, Inc.

Hennig, T.T., et al. 2004. Electronic Word-of-Mouth Via Consumer-Opinion Platforms: What Motivates Consumers to Articulate Temselves on The Internet? Journal of Interactive Marketing. Vol. 18 No. 1, pp. 38-52. 
Jalivand, M. and Samiei. 2011. The Effect of Electronic Word of Mouth on Brand Image and Purchese Intention, An empirical Study in the Automobile Industry in Iran", pp. 1-18. Diakses dari i-rep.emu.edu.tr:8080/.../Manuscript_Draft\%20updated\%20.

Keller, K.L. 1993. Conceptualizing, Measuring, and Managing Customer-Based Brand Equity. Journal of Marketing. Vol. 57 No. 1, pp. 1-22.

Kotler, P. and Keller, L. K. 2014. Marketing Management. Pearson International.

Lewis, R.C. and Chambers, R.E. 2000. Marketing Leadership in Hospitality. Foundations and Practices. Vol. III, Wiley, New York, NY.

Litvin, S.W., Goldsmith, R.E. and Pan, B. 2008. Electronic Word-of-Mouth in Hospitality and Tourism Management. Tourism Management., Vol. 29, pp. 458-68.

Park, D.-H. and Kim, S. 2008. The Effects of Consumer Knowledge on Message Processing of Electronicword-of-Mouth via Online Consumer Reviews. Electronic Commerce Research and Applications. Vol. 7, pp. 399-410.

Rowley, J. 2001. Remodelling Marketing Communications in An Internet Environment. Internet Research. Vol. 11 No. 3, pp. 203-12.

Sen, S. and Lerman, D. 2007. Why Are You Telling Me This? An Examination Into Eegative Consumer Reviews on The Web. Journal of Interactive Marketing, Vol. 21 No. 4, pp. 76-94.

Senecal, S. and Nantel, J. 2004. The Influence of Online Product Recommendations on Consumers' Online Choices. Journal of Retailing. Vol. 80 No. 2, pp. 159-69.

Subramani, M.R. and Rajagopalan, B. 2003. Knowledge-Sharing and Influence in Online Social Networks Via Viral Marketing. Communications of the ACM. Vol. 46 No. 12, pp. 300-7.

Wang, X. and Yang, Z. 2010. The Effect of Brand Credibility on Consumers' Brand Purchase Intention in Emerging Economies: The Moderating Role of Brand Awareness and Brand Image. Journal of Global Marketing, Vol. 23 No. 3, p. 177.

Xia, L. \& Bechwati, N.N. 2008. Word of Mouth: The Role of Cognitive Personalization in Online Consumer Reviews. Journal of Interactive Advertising. Vol. 9 No. 1, pp. 10828.

Zhang, R. and Tran, T. 2009. Helping e-Ecommerce Consumers Make Good Purchase Decisions : a User Reviews-Based Approach In Babin, G., Kropf, P. and Weiss, M. (Eds), E-technologies : Innovation in an Open World. Springer, Berlin, pp. 1-11.

Zhu, F. and Zhang, X. 2010. Impact of Online Consumer Reviews on Sales: the Moderating Role of Product and Consumer Characteristics. Journal of Marketing. Vol. 74 No. 2, pp. 133-48. 